GLOBAL JOURNAL OF AGRICULTURAL SCIENCES VOL. 6 NO. 2 2007: 191 - 194

\title{
COMPARISON OF COTTON SEED CAKE AND POULTRY LITTER AS PROTEIN SOURCES IN THE DIETS OF GROWING WADARA CATTLE FED BASAL DIET OF SORGHUM STOVER IN SEMI ARID REGION OF NIGERIA
}

B. IMAM, A. A. NJIDDA and A. KIBON

(Received 9 May, 2007; Revision Accepted 6 July, 2007.)

\section{ABSTRACT}

An experiment was conducted to compare the effect of feeding poultry litter and cotton seed cake on dry matter intake (DMI), dry matter digestibility (DMD), live weight gain and economic analysis of wadara cattle. Nine wadara cattle (males) aged two and a half years with a mean live weight of $187.4 \pm 0.67 \mathrm{~kg}$ were randomly allotted to three treatment groups. The treatments compared were: To (Contro!) reseived Sorghum Stover ad-libitum + wheat offal's at $2.5 \mathrm{~kg} / \mathrm{animal} / \mathrm{day}$; $T_{1}$ received sorghum stover ad-libitum + wheat offals at $1 \mathrm{~kg} /$ animal/day $+1.5 \mathrm{~kg} /$ animal $/$ day of poultry litter and $T_{2}$ received sorghum stover + wheat offals at $1 \mathrm{~kg} /$ animal/day $+1.5 \mathrm{~kg} / \mathrm{animal} / \mathrm{day}$ of cotton seed cake. All animals were housed and fed individually in pens with concrete flooi. The DMI were $3.62 \mathrm{~kg}, 4.75 \mathrm{~kg}$ and 4.86 for $T_{0}, T_{1}$ and $T_{2}$ respectively. Supplementing sorghum stover with poultry litter and cotton seed cake significantly $(P<0.05)$ increased DMI. The DMD were $66.7,68.6$, and $68.5 \%$ for $T_{0}, T_{1}$ and $T_{2}$ respectively. Live weigh gains were significantly different among treatment groups with $T_{0}, T_{1}$ and $T_{2}$ having $15.00,18: 34$, and $33.33 \mathrm{~kg}$ live weight gain. Supplementing sorghum stover with poultry litter or cotton seed cake resulted in an economic return. $T_{1}$ and $T_{2}$ recorded return of A7472.43 and $\$ 13555.8$ while To had $\$ 6031.17$.

KEY WORDS: Cotton seed cake, poultry litter, sorghum stover and supplement

\section{INTRODUCTION}

Borno state is a traditionally livestock rearing are of Nigeria and is also quantitatively the most importan cersal crop producing area. This area covers guinea and sudan savanna and the sahelian region. It has a mean annual rainiall of $300-900 \mathrm{~mm}$ (Thambyapillay, 1983), which falls from late May to early October. It is characterized by high ambient temperature ranging from 30 to 40 degrees centigrade and relative humidity of $13-42.5 \%$ (jere and Daura, 2000)

Most of the Nigeria's estimated 9.3million cattle are located in the northern state (Scarr, 1986), the region is the largest and the most important pastoral zones in Nigeria. Nigerian livestock resources (RIM, 1992) estimates that Borno state has about 2,726,999 heads of cattle, and experience a dry season of at least 5 - 6months during which animals consuming poor quality feeds lose weight (Scarr, 1986).

As feeds represent the greatest cost in livestock production, its availability is affected by seasonal variation in feed quantity and quality in this area and this causes fluctuations in animal productivity. Ray and Deleeuw (1974) listed three sources of feeds for ruminant livestock in Northern Nigeria and these include crop residues, pastures and browse plant. Adebowale (1985) reported that there is abundant farm wastes such as stover and straws during the dry season. It is estimated that $1.7,4.4$ and 5.9 million hectres of maize, millet and sorghum respectively are under cultivation annually in Nigeria (Egharevba, 1979); Anon., 1981). Others include rice, wheat etc. The importance of these crop residues as fodder is well recognized by local herdsmen. It is estimated that $40 \%$ of the dry season grazing time is spent by local cattle on crop residues (Powell, 1983)

Despite the availability of these crop residues in large quantities and their potentials as substantial feed resources, they are poorly utilized due to protein limitation for feeding livestock during the long dry season (Fomunyam and Mbomi, 1987). Mosi and Butterworth (1985) indicated that nitrogen content of most of the cereal crop residues is less than $1 \%$

Efforts to improve intake and utilization of these poor quality crop residues by animals have been through treatment (Sundstol, 1981) and supplementation with protein sources
(Kellaway and Leibholz, 1983). Treatment of crop residues with chemicals like alkali and urea, biologically by treating with enzymes or inoculants have been shown to be beneficial, but some of these chemicals and inoculants are expensive, corrosive or uneasy to handle and may even not be available to the local herdsmen. Supplementation with conventional concentrate fueds rich in protein on the other hand have not beën economically feasible due to its high cost, non or marginal returns after usage, demand for use by the increasing human population and feeding non ruminant livestock. To this effect, there is often need to explore the potentials of alternative sources of supplementary feeds rich in nitrogen, inexpensive and available that will improve the nutritive value of the poor quality crop residues for feeding ruminant livestock. Poultry litter, which is cheap and available, is a good source of protein for improving utilization of these available crop residues by ruminant fivestock. Poultry litter is usually rich in nitrogen, averaging $28 \%$ crude protein, half of which is a true protein and the remaining part is mostly uric acid and ammonia (Bhattacharya and Taylor, 1975). Uric acid is slowly broken down in the rumen resulting in a more efficient utilization of nitrogen with minimal risk of toxicity (Oltjen et al., 1968).

The objective of the study is therefore to compare the effects of feeding cotton seed cake and poultry litter as protein supplement on dry matter intake, dry matter digestibjlity and live weight change of wadara cattle.

\section{MATERIALS AND METHODS}

\section{Animals and Treatment}

Nine wadara cattle aged $2-3$ years with a mean live weight of $186 \pm 2.61 \mathrm{~kg}$ were used for the study. A randomized complete block design was used for the experiment. The animals were randomly allocated to three treatments with three animals per treatment. The treatments compared are

$r_{0}$ (Control) Sorghum stover (ad-libitum)

Wheat offals at $2.5 \mathrm{~kg} / \mathrm{animal} / \mathrm{day}$

$T_{8}$

Sorghum stover (ad-libitum)

Wheat offal at $1 \mathrm{~kg} /$ animal/day

Poultry litter $1.5 \mathrm{~kg} / \mathrm{animal} / \mathrm{day}$

B. Imam, Ministry of Animal and Fishery Development, Damaturu, Yobe State - Nigeria

A. A. Njidda, Department of Agricultural Science and Technology, Ramat Polytechnic P.M.B 1070, Maiduguri - Nigeria

A. Kibon, Department of Animal Science, University of Maiduguri, P. M. B. 1069, Maiduguri - Nigeria 
$T_{2}$

Sorghum stover (ad-libitum)

Wheat offal at $1 \mathrm{~kg} /$ animal/day

Cotton seed cake $1.5 \mathrm{~kg} /$ animal/day

Experimental Procedure

All animals were dewormed with albendazole bolus (Vermittan bolus) and housed in individual pens with free access to water and mineral licks. The study comprised of 14 days of feed adaptation period and 7 days measurement period. Feed offered twice daily at 8:00hrs and $16.00 \mathrm{hrs}$.

The animals were fitted with canvas bag around its rear end to collect feacal samples and total urine voided were recorded from each animal using measuring cylinders and sampled for chemical analysis. Sample of feed offered were taken daily during the measurement period for chemical analysis. Body weights of the animals were also measured at weekly intervals. Dry matter digestibility was determined at three weeks intervals using the formula given below

$\%$ Apparent digestibility $=$ dry matter intake - faecal dry matter

Dry matter intake

Chemical Analysis

Samples of the feeds and faeces were collected and bulked separately during the experimental period, sub-samples taken and was analyzed in triplicate for dry matter (DM), crude protein (CP), crude fibre (CF), ether extract (EE), nitrogen free extract (NFE) and ash according to AOAC (2002)

\section{Statistical Analysis}

The data obtained from the trial were analyzed using analysis of variance procedure in complete randomized block design (Steel and Torrie, 1980) to detect differences between treatment means.

\section{RESULTS ABND DISCUSSION}

\section{Proximate Composition of Experimental Diets}

The result of the chemical composition of the experimental diets is shown in Table 1. The poultry litter used in this study had a crude protein (CP) content of $18 \%$ on dry matter basis which is less than $29 \%$ CP dry matter (DM) basis analyzed for cotton seed cake. The $18 \%$ crude protein (CP) of poultry litter is within the range of $17.7 \%$ reported by Odhuba et al. (1986b) and $14-30 \%$ reported by Bhattachary and Taylor (1975) but lower than $28.5 \%$ reported by Jamrich and Farakas (1977). The variation in the crude protein content reported may be attributed to the composition of the feeds used or fed to the birds, frequenoy of removal and the concentration of dropping in the litter, the type of litter used and the density of birds in the poultry house. The cotton seed cake (CSC) had $29 \%$ CP is slightly higher than the $26.0 \%$ reported by Ehoche and Roffler (1982), but lower than the $41 \%$ reported by Allen (1982). The differences in value may be attributed to the quality of the supplement, as time taken under storage before supplementation and the technique employed in processing affects the quality of the product. This involved decortications to make the product palatable for animal consumption. The value of ether extract range from $1.50-14.00 \%$ with the highest value $14 \%$ in CSC. The higher value is due to the high oil content in the CSC. Mineral content range from $5.00-$ $15.00 \%$ with poultry litter $(\mathrm{PL})$ having the highest value $(15 \%)$ and lowest in sorghum stover though there was no significant difference between the ash content of $\mathrm{CSC}$ and $\mathrm{PL}$. The ash content of the $P L$ is higher than the $14 \%$ and $12.7 \%$ reported by Allen (1982) and Odhuba et al (1986). This variation may be due to the routine supplementation with mineral sources in intensive poultry production. Different category of birds receives different types of feeds with variation in feed composition and equally this may affect the composition of litter to be used for ruminant feeding. The $19 \%$ crude fibre (CF) in poultry litter is higher than $13 \%$ in cotton seed cake The higher CF content in PL may be attributed to the wood shaving based litter used in this study. Sorghum stover, which formed the basal diet, was more fibrous. Skerman and Riveros (1990) reported that the CF content ranges from 22$25 \%$ in young plants and from $30-40 \%$ in mature plants and is particularly high in tough fibrous grasses. The value of the $\mathrm{CF}$ is also similar to the value $(41.1 \%)$ reported by Ehoche and Roffler (1982). The nitrogen free extract (NFE) was also highest $(37.00 \%)$ in $T_{0}$ and lowest $(29.00 \%)$ in $T_{1}$

Table 1: Chemical composition of experimental diets

\begin{tabular}{llll}
\hline \multirow{2}{*}{ Ingredients (\%) } & \multicolumn{3}{c}{ TREATMENTS } \\
\cline { 2 - 4 } & $T_{0(\mathrm{SS})}$ & $\mathrm{T}_{1(\mathrm{PL})}$ & $\mathrm{T}_{2(\mathrm{CSC})}$ \\
\hline Dry matter (DM) & 92.10 & 91.20 & 93.00 \\
Crude Protein (CP) & 18.00 & 29.00 & 4.00 \\
Crude Fibre (CF) & 19.00 & 13.00 & 44.00 \\
Ash & 15.00 & 6.00 & 5.00 \\
Ether Extract (EE) & 7.60 & 14.00 & 1.50 \\
Nitrogen Free Extract (NFE) & 32.50 & 29.20 & 37.80 \\
\hline
\end{tabular}

SS = Sorghum Stover; PL $=$ Poultry Litter; CSC = Cotton Seed Cake

\section{Feed Intake and Digestibility}

The result of the feed intake and dry matter digestibility is shown in Table 2. The intake of stover was not significantly different $(P>0.05)$, this therefore, showed that supplementing the stover with poultry fitter (PL) and cotton seed cake. (CSC) signified the increase in total dry matter intake (DMI). Substitution of stover was observed following supplementation with PL and CSC. The result aiso showed that supplementation with PL and CSC increases the DMI of the experimental animals significantly $(P<0.05)$. Thus the $D M I$ were significantly higher for the supplemented grous compared to the control animals $\left(T_{0}\right)$. DMI of $T_{2}$ is higher compared to animals on $T_{1}$. Lower intake observed in $T_{1}$ may be attributed to the depression of intake caused by the poultry litter. This is also evidenced from the lower stover intake in the treatment group. The result is consistent with the work of Adu and Lakpini (1983). Trung et al., (1984) though the results is in contrast to the findings of Njidda et al. (2007) who observed higher DMI of sheep when fed PL during the wet season. The level given in this study is higher than the $25 \%$ reported by these researchers. Lower intake due to poor palatability of poultry had also been reported by Tinnimit et al. (1975) Though the DMI was significantly $(P<0.05)$ increased by $P L$ supplementation, this increase is not highly reflected in weight gain of the animals in the treatment group. In $T_{2}$, the supplement was highly relished by the animals due to its palatability with a consequence of substitution as observed from the lower intake of sorghum stover. Increase in DMI and palatability due to CSC supplementation had been supported by the report of Alhassan et al., (1986) and Formunyam and Mboni (1987). Preston and Leng (1987) also reported that a limit of $20 \%$ supplementation with oil seed cakes prevent depression. Higher than $20 \%$ offered in the study consequently resulted to reduction in the intake of basal diet.

The result of the dry matter digestibility (DMD) is shown in Table 2. There is no significant difference $(P>0.05)$ in DMD due to either PL or CSC supplementation, though the DMD tend to increase in supplemented groups than the control groups. The DMD was increased by approximately $2 \%$ in supplemeried groups. The presence of sorghum stover in the rumen for a longer time as evidenced from the crude fibre content, and as fibrous diets are often low in nitrogen with the result that fermentation or extent of microbial proliferation is limited by the rumen concentration of ammonia, the supplemented PL stimulated the rumen microbes to digest the feed materials ingested. It aided in the supply of needed ammonia through the breakdown of uric acid which is ultimately utilized by the rumen microbes for digestion. The apparent digestibility of $T_{1}$ is higher than the reports of Orskov (1986) and Odhuba et al. (1989) but within the range reported by Olayiwole and Olurunju (1986). The higher digestibility coefficient may be due to the higher quantity of PL supplemented to the animals in this study, the type of ration fed to the animals and the type and specie of animals used in the study may also serve as a factor to bring difference in digestibility coefficient. The difference obtained with the resuit of Olayiwole and Olurunji (1986) was due to the presence of 
molasses, which serve as an energy source and the pretreatment before supplementation with $\mathrm{PL}$. The high coefficient of digestibility encountered in CSC supplementation is evidenced from the high content of $\mathrm{CP}$. It helped in stimulating the rumen microbes to degrade the materials ingested. This is supported by Ehoche and Roffler (1982), they indicated a digestion of sizeable portion (55\%) of CSC in the rumen and favourably stimulated the rumen microbes to degrade the ingested fibrous materials. It supplied the needed nitrogen to the microorganism for efficient digestion.

Table 2: Mean dry matter intake and dry matter digestibility of wadara cattle fod sorghum stover supplemented with poultry litteer or cotton seed cake

\begin{tabular}{lllll}
\hline & \multicolumn{5}{c}{ Treatments } \\
\cline { 3 - 6 } Ingredienis $(\%)$ & $\mathrm{T}_{0}$ & $\mathrm{~T}_{1}$ & $\mathrm{~T}_{2}$ & $\mathrm{SEM}$ \\
\hline Stover intake $(\mathrm{kg})$ & 2.71 & 2.45 & 2.56 & $0.12^{\mathrm{NS}}$ \\
Total dry matter intake $(\mathrm{kg})$ & 3.62 & 4.75 & 4.86 & $0.12^{*}$ \\
Dry matter digestibility $(\%)$ & 66.73 & 68.69 & 68.50 & $2.08^{\mathrm{NS}}$
\end{tabular}

$a, b$ and $c=$ means with different superscripts within the same now are significantly different $(P<0.05)$; $=$ Significant $(P<0.05)$ $S E D=$ standard error of difference between two means

\section{Live Weight Change}

The result of the live weight change is shown in Table 3 . There is a significant effect $(P<0.05)$ on live weight gain and daily live weight gain due to supplementation with PL or CSC when compared to the control gioup $\left(T_{0}\right)$. Higher live weight gain observed in $T_{2}$ was possibly due to the supply of rumen undergradable protein which by-pass the rumen degradation and ultimately digested in the small intestine. This is supported by Ehoche and Roffler (1982). They reported that an estimated $45 \%$ of the CSC protein escaped the ruminal degradation. Kellaway and Leibholz (1983) had proven the low rumen degradability of CSC into the small intestine. This work is in line with the work of Delgardo et al (1979). They reported a two-two-fold increase in live weight after supplementation with ( $50 \%$ by weight) oil seed cake compared to $(100 \%$ by weight) poultry litter. The data indicated that poultry litter is not a good source of by-pass protein. The lower live weight gain observed in $T_{1}$ was possibly due to the very low quantity of by-pass protein as evidenced from its chemical characteristic. Bhattachanya and Taylor (1975) had reported that half the quantity of crude protein in $\mathrm{PL}$ is true protein and the remaining part is mostly uric acid and ammonia. This quantity is low to support maximum growth. Preston and Leng (1987) reported that high growth ratio cannot be supported and the products of fermentative degradation and that by-pass protein supplements are essential to take advantage of the volatile fatty acids energy absorbed. Simialrly. Verner (1984) reporled that the supply of amino acid to the animal might be too low to support maximum growth if only non-protein nitrogen (NPN) is given as the nitrogen supplement. Trung et al (1984) also reported a poor gain in live weight when PL was given at high levels.

Table 3: mean live weight and live weight change of wadara cattle fed sorghum stover supplemented with poultry litter or cotton seed cake treatments

\begin{tabular}{|c|c|c|c|c|}
\hline Ingredients (\%) & $T_{0}$ & $T_{1}$ & $\mathrm{~T}_{2}$ & SEM \\
\hline Initial weight (kg) & 187.33 & 187.61 & 187.42 & - \\
\hline Final weight (kg) & $200.33^{C}$ & $205.00^{b}$ & $220.66^{4}$ & $3.07^{\circ}$ \\
\hline Live weight gain (kg) & $15.00^{\circ}$ & $18.34^{b}$ & $33.33^{*}$ & $1.33^{*}$ \\
\hline $\begin{array}{l}\text { Daily live weight gain } \\
\text { (kg) }\end{array}$ & $0.24^{c}$ & $0.29^{6}$ & $0.53^{n}$ & $0.02^{\circ}$ \\
\hline
\end{tabular}

(kg)

$a, b$ and $c=$ means with different superscripts within the same nov are significantly different $(P<0.05)$; " $=$ Significant $(P<0.05)$ SED = standard error of difference between two means

\section{Economic Analysis}

The result of the economic analysis is shown in Table 4. The result shows that supplementing sorghum stover with poultry litter and cotton seed cake had a higher economic return than the unsupplemented group. The main essence of supplementation is to increase the live weight of the animal so as to have higher economic return after sales that will support the cost of inputs incurred. Feed cost was higher in $T_{1}$ and $T_{2}$. This is evidenced from the higher level of more costly cottonseed cake supplemented to the animals in the treatment group. Profit after sales was higher in $T_{2}$ than in $T_{1}$ with the least in $T_{0}$. The higher return was due to the higher live weight gain of the animals in $T_{2}$ followed by $T_{1}$ and $T_{0}$. The result reveals that the economic return of the supplemented groups is higher compared to unsupplemented group with the margin being higher in $T_{2}$ despite is highest feed cost.

Table 4: Economic analysis of wadara cattle-fed sorghum stover alone supplemented with poultry litter or cotton seed cake

\begin{tabular}{|c|c|c|c|c|}
\hline \multirow[b]{2}{*}{ Ingredients (\%) } & \multicolumn{3}{|c|}{ TREATMENTS } & \multirow[b]{2}{*}{ SEM } \\
\hline & $T_{0}$ & $T_{1}$ & $T_{2}$ & \\
\hline Initial weight $(\mathrm{kg})$ & 187.33 & 186.66 & 187.33 & - \\
\hline Final weight (kg) & $200.33^{c}$ & $205.00^{b}$ & $220.65^{a}$ & $3.07^{\circ}$ \\
\hline $\begin{array}{l}\text { Live weight gain } \\
(\mathrm{kg})\end{array}$ & $15.00^{c}$ & $18.34^{b}$ & $33.33^{\mathrm{a}}$ & $1.33^{\circ}$ \\
\hline Price/kg.beef (N) & 450 & 450 & 450 & \\
\hline Price/gain (A) & 6,750 & 8,253 & $14,998.5$ & - \\
\hline Feed cost $(\mathbf{N})$ & 6031.17 & 780.57 & $1,442.7$ & \\
\hline $\begin{array}{l}\text { Return margin } \\
\text { (N) }\end{array}$ & $6,031.17$ & 7.472 .93 & 13.555 .8 & \\
\hline
\end{tabular}

$a, b$ and $c=$ means with different superscripts within the same now are significantly different $(P<0.05) ;=$ Significant $(P<0.05)$ SED = standard error of difference between two means

\section{CONCLUSION}

From the result it can be concluded that supplementing sorghum stover with $\mathrm{PL}$ and CSC is of immense importance if proper rationing and strategic feeding have been employed in ruminant production. The result also showed that supplementing sorghum stover with poultry litter increased DMI, DMD with lower live weight gain of the animals in $T_{2}$. Supplementation with CSC increase DMI and live weight gain of the animals in $T_{2}$, DMO was also high. Higher economic return of almost a two-fold was seen in CSr. supplementation as compared to that of PL. If itemized, the cost of input was high with CSC due to the cost of the supplement, and higher economic gain due to the higher live weight gain of the animals.

\section{REFERENCES}

Adebowale, E. A., 1985. Non conventional fegd resources in Nigeria. NIFOJ 1, 2, 3. Pp. 181

Adu, I. F. and Lakpini, C. A. M., 1983. The utilization of dried poultry waste as protein supplement for growing Yankasa sheep. J. Anim. Prod. Res. 3 (1): 49-56.

Alhassan, W. S., Ehoche, O. W. and Adu, I. F., 1986. Infuence of graded levels of cotton seed cake supplementation on the nutritive value of cereal straw by sheep and goats J Anim. Prod. 691 ): 39-54.

Allen, R. D., 1982. Feedstuff Analysis Table Feedstuffs. Minneapolis. Pp. 25-31 (cited by Preston and Lerg. 1987). 
Anon., 1981. IAR cropping scheme meeting report. Inst. for Agric. Res. Ahmadu Bello University Samaru, Zarin, Nigeria.

AOAC., 2002. Official Methods of Analysis of official Analytical Chemists (W. Hontż ed.) $17^{\text {th }}$ Edition, Association of Analytical Chemists, Washington D.C.

Bhattachanya, A. N. and Taylor, J. C., 1975. Recycling of animal waste as a feedstuff. A Review. J. Anim. Sci. 41: $1438-1457$

Delgardo, A., Eliab, A., Veitia, A. L. and Garcia, A., 1979. The use of pasture for beef production. A poultry litter/sunflower cake meal rations in the supplementation of bulb grazing pangola grașs during the dry season. Cuban J. Agric. Sci. 13: 265-272

Egharevba, P. N., 1979. Trends and constraints in millet production. Nat. Ascolcrs Food prod. Prog. Workshop, Zaria, Nigeria.

Ehoche, O. W. and Roffler, R. E., 1982. The proportion of supplemental protein escaping degradation in the rumen of cattle. J. Anim. Prod. Res. 2 (1): 11-29

Fomunyam, R. T: and Mboni, S. E., 1987. Teprosia spp and cotton seed cake supplementation of rice and maize stalks fed to sheep and goats in the dry season. Proc: Of the fourth annual workshop held at the Institute of Animal Research, Bamenda, Cameroun, $20-27^{\text {th }}$ October 1987. P. 143

ljere, J. A. and Daura, M. M., 2000. "Borno State" In: Mamman, A. B., Oyebanii, J. O. and Peters, S. W. (eds). Nigeria: A People United, A Future Assured. Volume 2. Gabumo Publishers, Calabar.

Jambrich, J. and Farakas, J.,1977. Kanferensia ozuziet karani potravinars kych odpadov. (Conference on utilization of food industry refuse). Bratislava pp. 11-21

Kellaway, R. C. and Leibholz, J., 1983. Effect of nitrogen supplements on intake and utilization of low quality forages. World Anim. Rev. 48: 33-37.

Mosi, A. K. and Buttenworth, M. H., 1985. The intake and digestibility by sheep of oat straw and maize stover fed with different levels of rough meal. Anim. Feed Sci. and Tech. (In press)

Njidda, A. A, Kibon, A and Ngoshe, A. A., 2007. Effect of cotton seed cake and dry poultry litter supplementation on performance and growth rate of grazing sheep in the sub-sahelian zone of Borno state. J. Appl. Sci. 10 (.1); $6763-6773$.

Odhuba, E. K., Magadi, d. P. and Sanda, I. A., 1986b. Poultry waste in cattle rations. 1. Utilization of broiler litter as a source of nitrogen in semi-intensive feed lot rations. E. Afri. Agric. J. 52: 16-21

Olayiwole, M. B. and Olurunju, S. A., 1986. Feedlot performance of yearling steers previously maintained on different crop residues/supplement regimes. In: Utilization of agricultural by-product as animal feed in Africa. D.A. Little and A. N. Said (eds). Proc. Of a workshop held at Balantyre, Malawi September 1986. pp. 77-80.
Oltijen, R. R. Slyter, L. E. Kozak, A. S and William, E. E. 1968. Evaluation of urea, biuret, urea phosphatre and uric acids as non-protein ' nitrogen sources for cattle. J. Nutri. 94: 193-202

Orskov, E. R., 1986. Strategies for rural development with emphasis on livestock production, resources utilization and F.A.D. assistance. In: Utilization of agriculture by-products as livestock feed in Africa D.A. Little and A. N. Said (eds). Proc. Of Workshop held at Balantyre, Malawi September 1986. Pp. 154164

Powel!, J. M., 1983. ILCA's research on crop-livestock interactions in the sub-humid zone of Nigeria. Seminar on collaborative research in Agriculture (ACIAR), Zaria, Nigeria.

Preston, T. R. and Leng, R. A., 1987. Matching ruminant production system with available resources in the tropics and sub-tropics. Penambur Books, Armidale P.108

Ray, J. G. T and Deleeuw, P. M, 1974. The importance of crop residue as fodder: Res. Analysis in katsina Province Nigeria. Samaru Research Bulletin: 139

RIMS., 1992. Resources Inventory and Management Limited Nigerian Livestock Resources. Executive summary and Atlas (11) National Synthesis State Reports (iV) reports and commercially managed livestock survey reports, pp. 1-1612.

Scarr, M. J., 1986. The optimal use of agro-industrial by products crops residues in Nigeria. In: Utilization of agricultural by-product as livestock feed in Alrica D.A. Little and A. N. Said (eds). Proc. Of a workshop held at Malawi, September, 1986, Pp. 157

Skerman, P. J. and Riveros, F., 1990. Tropical grasses, plant production and protection series 23 , Rome: FAO

Steel, R. G. and Torriem, J. H., 1980. Principles and procedure of statistics. McGraw-Hill, New York, pp. 132-219.

Sundstol. F., 1981. Methods for treatment of low quality roughages. In; Utilization of low quality roughages in Africa. Proc Workshop, Amisha, Tanzania. AUNAgric. Dev. Report. AUS, Norway

Thambyapillay, G. G. R. 1983. The Paleo-hydro-climatology of Lake Chad. Annals of Borno. 1: 105-145.

Tinnimit, P., Yu, Y., McQuffey, K. and Thomas, J. W., 1975. Dried animal waste as a protein supplement for sheep. J. Anim. Sci. 35: 431-435.

Trung, L. T, Abenir, E. E., Palo, L. P., Matias, J. H., Riversa

C. C. and Capanid, R. R., 1984. Lancaeus lencocephal and other supplementary value of ipid ipid or dried poultry manure to rice straw for dairy heifers. Phil. Agric. 67 (4): $379-390$

Verner, F. K., 1984 Straw in practical rations for cattle. In straw and other Fibrous by-products as feed. $F$ Sundstol and $E$ Owen (eds) Felsevier, Amsterdam Pp. 443 